In cooperation with the Southern Division Naval Facilities Engineering Command

\title{
Use of Borehole Geophysical Logs for Improved Site Characterization at Naval Weapons Industrial Reserve Plant, Dallas, Texas
}

Water-Resources Investigations Report 00-4150 


\section{U.S. DEPARTMENT OF THE INTERIOR}

Bruce Babbitt, Secretary

\section{U.S. GEOLOGICAL SURVEY}

Charles G. Groat, Director

Any use of trade, product, or firm names is for descriptive purposes only and does not imply endorsement by the U.S. Government.

For additional information write to

\section{District Chief}

U.S. Geological Survey

8027 Exchange Dr.

Austin, TX 78754-4733

Email: dc_tx@usgs.gov

Copies of this report can be purchased from

U.S. Geological Survey

Branch of Information Services

Box 25286

Denver, CO 80225-0286

Email: infoservices@usgs.gov 


\section{CONTENTS}

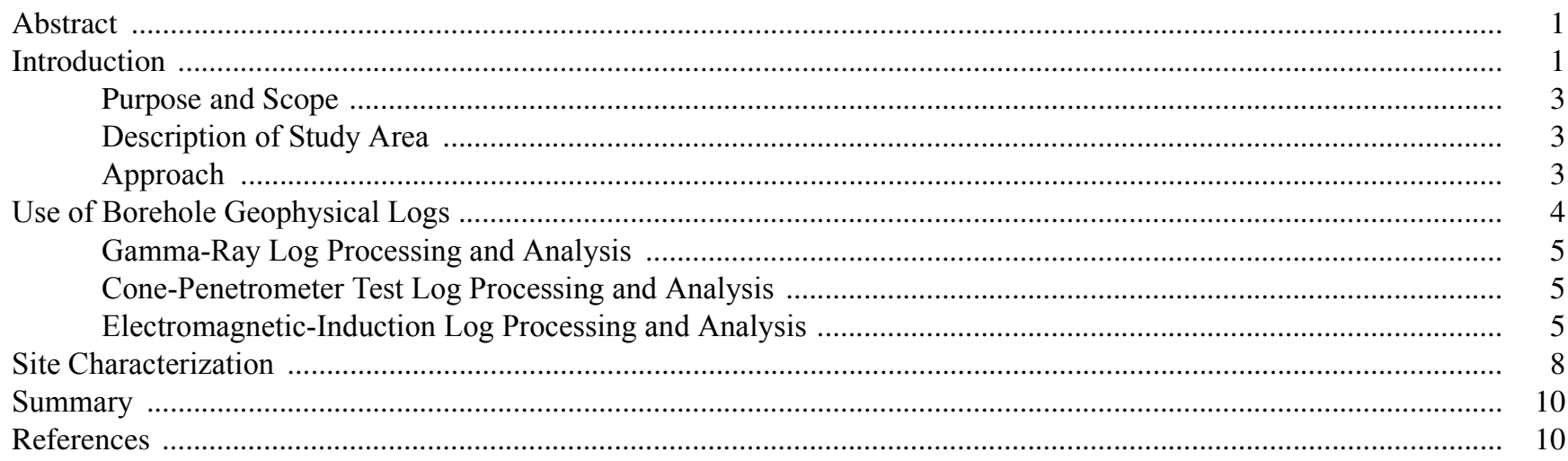

\section{PLATES}

Plates are in pocket

1-3. Maps showing:

1. Lines of section and logged well locations, Naval Weapons Industrial Reserve Plant, Dallas, Texas

2. Lithologic sections $A-A^{\prime}, C-C^{\prime}, D-D^{\prime}$, and $F-F^{\prime}$ at Naval Weapons Industrial Reserve Plant, Dallas, Texas

3. Lithologic sections $G-G^{\prime}, L-L^{\prime}, M-M^{\prime}, P-P^{\prime}, Q-Q^{\prime}$, and $R-R^{\prime}$ at Naval Weapons Industrial Reserve Plant, Dallas, Texas

\section{FIGURES}

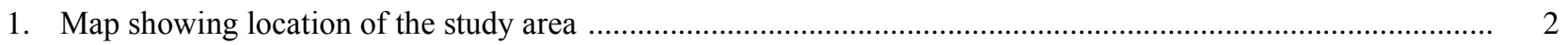

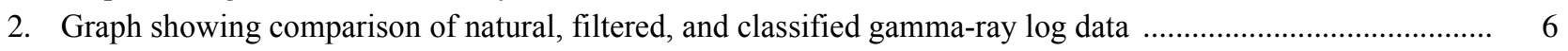

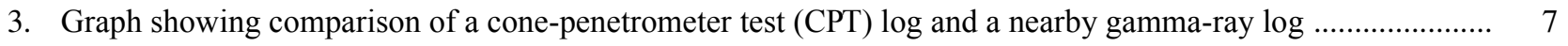

4. Boxplots showing range and distribution of conductivity for wells with no detected contaminants ................. 8

\section{TABLE}

1. Statistics for clay-content sediment classes in uncontaminated areas of the shallow alluvial aquifer

\section{VERTICAL DATUM, ABBREVIATIONS, AND ACRONYMS}

Sea level: In this report "sea level” refers to the National Geodetic Vertical Datum of 1929 (NGVD of 1929)—a geodetic datum derived from a general adjustment of the first-order level nets of both the United States and Canada, formerly called Sea Level Datum of 1929.

\footnotetext{
Abbreviations:

$\mathrm{cm} / \mathrm{s}$, centimeter per second

cps, counts per second

${ }^{\circ} \mathrm{F}$, degree Fahrenheit

$\mathrm{ft}$, foot

$\mathrm{ft} / \mathrm{s}$, foot per second
} 
$\mathrm{gal} / \mathrm{d}$, gallon per day

$\mathrm{gal} / \mathrm{min}$, gallon per minute

in., inch

$\mu \mathrm{g} / \mathrm{L}$, microgram per liter

mi, mile

$\mathrm{mS} / \mathrm{m}$, millisiemens per meter

\section{Acronyms:}

CPT, cone-penetrometer test

EM, electromagnetic

GOCO, government-owned, contractor-operated

NAS, Naval Air Station

NWIRP, Naval Weapons Industrial Reserve Plant

RCRA, Resource Conservation and Recovery Act

RFI, RCRA Facility Investigation

SOUTHDIV, Southern Division Naval Facilities Engineering Command

TCE, trichloroethene

USGS, U.S. Geological Survey 


\title{
Use of Borehole Geophysical Logs for Improved Site Characterization at Naval Weapons Industrial Reserve Plant, Dallas, Texas
}

\author{
By Roberto Anaya, Christopher L. Braun, and Eve L. Kuniansky
}

\section{Abstract}

A shallow alluvial aquifer at the Naval Weapons Industrial Reserve Plant near Dallas, Texas, has been contaminated by organic solvents used in the fabrication and assembly of aircraft and aircraft parts. Natural gamma-ray and electromagnetic-induction log data collected during 1997 from 162 wells were integrated with existing lithologic and cone-penetrometer test log data to improve characterization of the subsurface alluvium at the site. The alluvium, consisting of mostly fine-grained, low-permeability sediments, was classified into low, intermediate, and high claycontent sediments on the basis of the gamma-ray logs. Low clay-content sediments were interpreted as being relatively permeable, whereas high claycontent sediments were interpreted as being relatively impermeable. Gamma-ray logs, cone-penetrometer test logs, and electromagneticinduction logs were used to develop a series of intersecting sections to delineate the spatial distribution of low, intermediate, and high clay-content sediments and to delineate zones of potentially contaminated sediments.

The sections indicate three major sedimentary units in the shallow alluvial aquifer at NWIRP. The lower unit consists of relatively permeable, low clay-content sediments and is absent over the southeastern and northwestern part of the site. Permeable zones in the complex, discontinuous middle unit are present mostly in the western part of the site. In the eastern and southeastern part of the site, the upper unit has been eroded away and replaced by fill material. Zones of potentially contaminated sediments are generally within the uppermost clay layer or fill material. In addition, the zones tend to be local occurrences.

\section{INTRODUCTION}

A Resource Conservation and Recovery Act (RCRA) Facility Investigation (RFI) is being conducted by the Department of the Navy, Southern Division Naval Facilities Engineering Command (SOUTHDIV) at the Naval Weapons Industrial Reserve Plant (NWIRP) located southwest of Dallas, Texas, in Grand Prairie (fig. 1). A base closure is underway at the adjacent Naval Air Station (NAS).

Military and commercial aircraft have been built at NWIRP since the plant began operation in 1941. The facility is a government-owned contractor-operated (GOCO) plant. Vought Aircraft operated the facility from 1948 to 1994, and Northrup Grumman has operated the plant since 1994. Fabrication and assembly of aircraft and aircraft parts require the use of various organic solvents, paints, metals, oils, fuels, and other toxic chemicals.

Previous studies by EnSafe/Allen \& Hoshall (1994, 1996a), the firm conducting the RFI, indicated the presence of a dissolved-phase solvent plume in the shallow alluvial aquifer beneath NWIRP and the adjacent NAS. Chemical analysis of water samples from monitoring wells indicate the presence of organic solvents, such as trichloroethene (TCE) at concentrations ranging from less than analytical detection levels to $27,000 \mu \mathrm{g} / \mathrm{L}$.

Concern about the fate and transport of the organic solvents in the ground water led SOUTHDIV to request that the U.S. Geological Survey (USGS) conduct a study to develop a better understanding of the geohydrology of the site and to characterize the subsurface alluvium. Mapping the permeable zones within the alluvial aquifer will aid in the development of hydraulic 


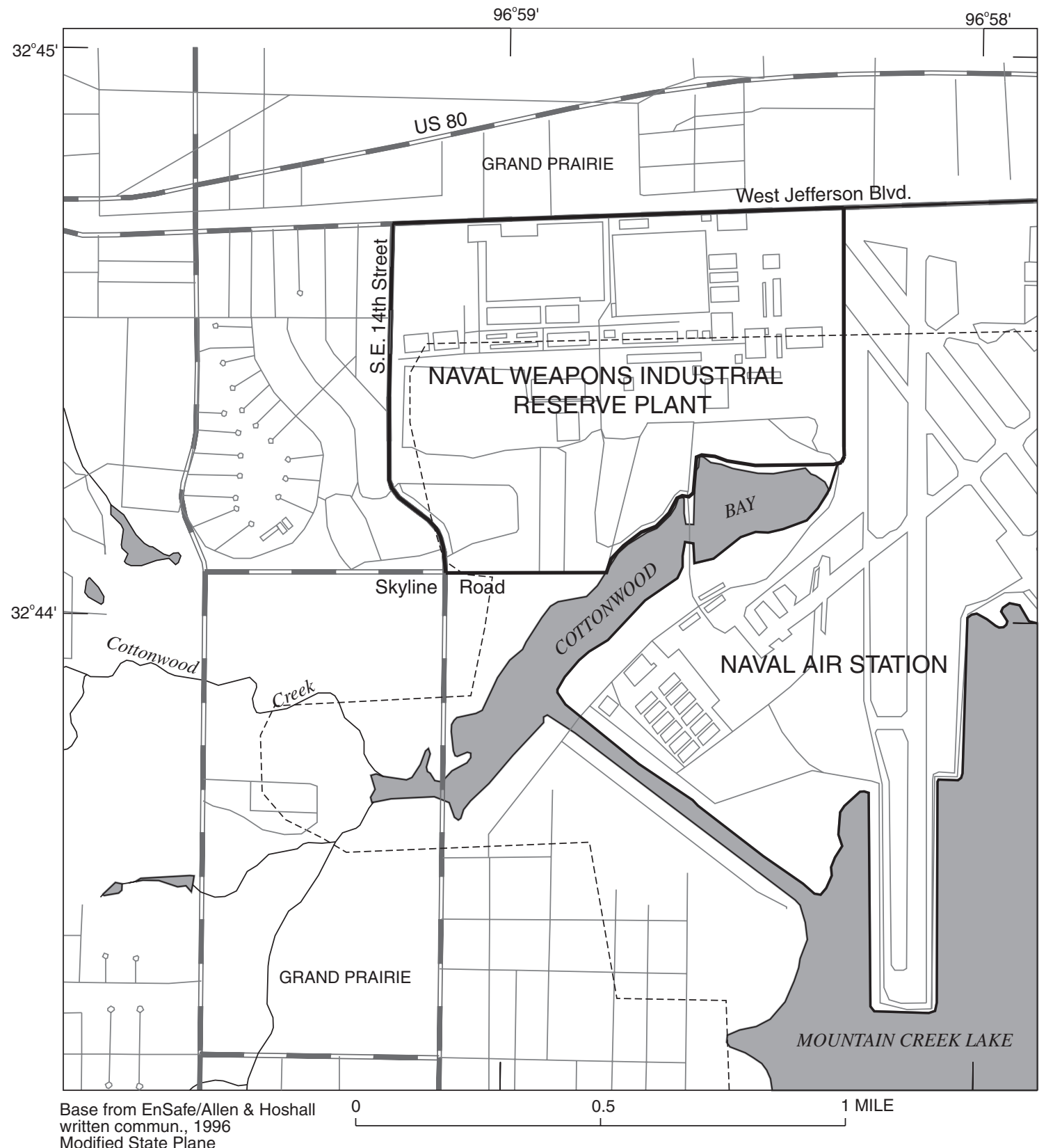

written commun., 1996

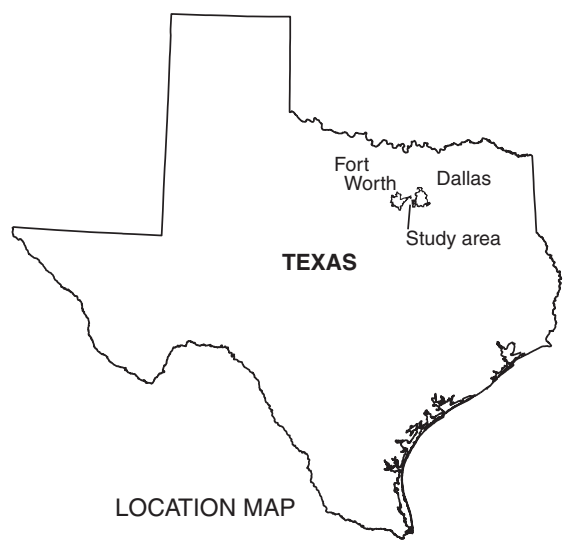

Figure 1. Location of the study area. 
containment strategies for prevention of off-site migration of the solvent plume and in the design of remedial actions for the contaminated ground water.

The aquifer consists of fine-grained alluvial sediments deposited over bedrock shale. The complex deposition of sediments with heterogeneous permeabilities, characteristic of alluvial deposits, typically yields a spatially variable permeability distribution with vertical anisotropy, and consequently, stratification of the ground-water contaminant plume. Cone-penetrometer test (CPT) log and descriptive lithologic data were available for subsurface geologic site characterization (EnSafe/Allen \& Hoshall, 1994, 1996a). Lithologic logs are subjective, involving the field description of the sediments without the aid of laboratory tests for grain-size distribution and mineralogy. The lithologic logs were prepared by several geologists, resulting in varied descriptions of the sediments. Natural gamma-ray and electromagnetic (EM)-induction logs, which were collected by the USGS in 1997, provide an objective method for classifying the relative clay content of subsurface sediments and for distinguishing relatively permeable zones from relatively impermeable zones. These borehole geophysical log data were integrated with existing lithologic and CPT log data to determine the relative clay content and conductance of subsurface materials. A comparative analysis of these data was performed to provide better information for delineating the spatial distribution of aquifer permeabilities and to aid in the identification of potentially contaminated versus uncontaminated permeable zones in the alluvium. This information was subsequently used in a multilayer ground-water-flow and transport model for NWIRP.

\section{Purpose and Scope}

This report describes the use of borehole geophysical logs and lithologic logs for improved subsurface characterization at NWIRP and presents the results of the log interpretations in the form of multiple lithologic sections. This report also documents the interpretations of the geophysical logs used in the lithologic sections.

\section{Description of Study Area}

The study area is in north-central Texas in Dallas County adjacent to the city of Grand Prairie, southwest of Dallas. NWIRP (314 acres) is bounded on the east by
NAS (837 acres), on the south by Cottonwood Bay, and on the north and west by residential, commercial, and industrial areas of Grand Prairie (fig. 1). The NWIRP site is relatively flat and drains into Cottonwood Bay and Mountain Creek Lake, which drain into the West Fork Trinity River about $4 \mathrm{mi}$ to the northeast. Landsurface altitudes range from 502 to $460 \mathrm{ft}$ above sea level west to east and from 496 to $462 \mathrm{ft}$ above sea level north to south (Jones and Paillet, 1997).

The climate is subhumid with summers generally long and hot (mean maximum July temperature during 1961-90 about $96^{\circ} \mathrm{F}$ ) and winters generally short and mild (mean minimum January temperature during 1961-90 about $35^{\circ} \mathrm{F}$ ) (Ramos, 1997). The average annual precipitation during 1961-90 was 32 in., with most of the precipitation occurring during spring and fall.

NWIRP is located on a stream terrace about 40 to $80 \mathrm{ft}$ above the current flood plain of the West Fork Trinity River. The terrace alluvium is composed of Quaternary alluvial deposits and underlain by the Upper Cretaceous Eagle Ford Shale, which dips very gently to the east-southeast. The Upper Cretaceous Austin Chalk and Taylor Marl overlie the Eagle Ford Shale in eastern Dallas County. However, in western Dallas County where NWIRP is located, the Austin Chalk and Taylor Marl were removed by erosion during the late Tertiary Period to produce an unconformable contact between the Eagle Ford Shale and the Quaternary alluvial deposits (Dallas Geological Society, 1965).

The alluvial aquifer at NWIRP ranges in thickness from about 10 to about $75 \mathrm{ft}$ and consists of fine sand, silt, and clay. EnSafe/Allen \& Hoshall (1994) identified three distinct water-yielding zones separated by thin, silty, clay layers. Pumping tests at more than 20 wells produced 1.5 to $2.0 \mathrm{gal} / \mathrm{min}$ of sustained flow from each well (Jones and Paillet, 1997). The bluishblack Eagle Ford Shale forms an underlying confining unit.

\section{Approach}

USGS personnel used portable geophysical welllogging equipment with a natural gamma-ray sonde and an EM-induction sonde to log 162 polyvinyl-chloridecased wells at NWIRP during July and August 1997. At nested piezometer sites, only the deepest well was logged. Each day, logging proceeded from the least contaminated wells to the most contaminated wells on the 
basis of TCE concentrations from EnSafe/Allen \& Hoshall (1996b). The geophysical-sonde probe and wetted cable were decontaminated after each use with a phosphate-free detergent wash. A scrub brush was used to remove mud from the probe, and both the probe and wetted part of the cable were rinsed with potable water. Northrup-Grumman granted permission for disposal of the rinsate, less than $2 \mathrm{gal} / \mathrm{d}$, at a decontamination facility. Personnel tried to maintain a constant logging speed of $20 \mathrm{ft} / \mathrm{min}$ at each well. The geophysical log data were collected in digital form in the field using a laptop personal computer, stored on floppy disk, and subsequently entered into a database for analysis and graphical display.

After field data collection, well-construction and descriptive lithologic information were entered into ASCII text files for plotting with the geophysical logs. Because the depths of most of the existing wells at the site were less than $25 \mathrm{ft}$, deeper CPT logs (EnSafe/Allen $\&$ Hoshall, 1994, 1996a) were digitized to augment the gamma-ray and EM-induction logs. The Perl programming language was used to develop software for filtering the data (reducing statistical variations); for classifying the clay content of the sediments (assigning ranges of low, intermediate, and high on the basis of the natural gamma-ray logs); for integrating the gamma-ray and EM log data with lithologic descriptions; and for processing, analyzing, and creating graphical output of the digital data.

After the clay content of the sediments was classified on the basis of the gamma-ray logs, the EM log data for wells located in uncontaminated areas were grouped by clay-content classification to determine the range of conductivity for each class of sediment. Simple statistical tools were used to verify that each class was unique and to determine the median and standard deviation of the conductivity of the sediments in uncontaminated areas. Conductivities greater than or equal to the median plus one standard deviation for a particular sediment class were interpreted as having anomalously large dissolved solids concentrations in the ground water at that location. Software was developed to define and plot the locations of these anomalous conductivity values.

Profiles of well logs were created using a program that integrated the filtered gamma-ray and CPT log data, classified gamma-ray and CPT log data, wellsurface altitudes, well-bottom altitudes, and distances between wells for each lithologic section. The surface profiles and well logs were provided to each author for correlation of relatively permeable and relatively impermeable zones. After joint resolution of any discrepancies between interpretations, the sections were verified for agreement where they intersected at common wells. The correlated permeability zones were digitized after several review cycles. The sections were plotted again for visual analysis of the subsurface characterization of relatively permeable and relatively impermeable sediments.

\section{USE OF BOREHOLE GEOPHYSICAL LOGS}

The natural gamma-ray log provides a record of the natural gamma radiation detected in a borehole from materials within about $1 \mathrm{ft}$ of the sonde (Keys and MacCary, 1971). The emission of natural gamma-ray particles is directly related to the amount of clay within rock materials because clay minerals have a higher percentage of radioactive potassium, thorium, and uranium isotopes than do many other minerals in sedimentary rocks. Gamma-ray logs have been used extensively in alluvial deposits to provide quantifiable data on the clay content of lithologic units. A clean sand produces gamma-ray particle emissions at a much lower rate than a silty clay. Because the permeability of a lithologic unit is inversely related to the amount of clay sediments within the lithologic unit, a silty sand or sandy clayey silt on a lithologic log can be compared with the gamma-ray log to quantify the relative clay content and thus, the relative permeabilities of subsurface sediments. Low clay-content sediments are considered relatively permeable, whereas high clay-content sediments are considered relatively impermeable.

As the CPT unit is pushed into the sediments at a constant rate of $2 \mathrm{~cm} / \mathrm{s}(0.07 \mathrm{ft} / \mathrm{s})$, the log continuously records the sleeve friction (in tons per square foot), the tip resistance (in tons per square foot), and the ratio between the two (as a percentage) (EnSafe/Allen \& Hoshall, 1996c). The ratio of sleeve friction to tip resistance is directly related to the amount of clay within the sediment. These ratios typically are compared to a computer library to assign relative clay content.

The EM-induction log records the conductivity and resistivity of materials within about $3 \mathrm{ft}$ of the sonde (McNeill and others, 1990). The conductivity of aquifer materials is sometimes used to identify zones of ground- 
water contamination. In a study of a sand and gravel aquifer of glacial origin, the conductivity ranged from less than 5 to $10 \mathrm{mS} / \mathrm{m}$ for uncontaminated waterbearing zones of clean sand and gravel, from 15 to 45 $\mathrm{mS} / \mathrm{m}$ for uncontaminated water-bearing zones of silt and clay, and from 10 to $80 \mathrm{mS} / \mathrm{m}$ for contaminated water-bearing zones of sand and gravel (Williams and others, 1993).

\section{Gamma-Ray Log Processing and Analysis}

Gamma-ray log data, radiation emission recorded in counts per second, were obtained with a scintillometer-logging sonde at 0.1 -ft downhole intervals and were sent uphole digitally. The same gammaray logging sonde was used to collect all gammaray log data at the site over a relatively short period (15 days) to mitigate the effects of uncalibrated raw gamma-radiation emissions. Natural gamma radiation is a random phenomenon and, thus, produces variable emissions even when the sonde is stationary (Schlumberger, 1972). A program was created to filter the statistical variations of the data with a user-defined onedimensional, weighted-average convolution (moving window) algorithm. Using a trial-and-error approach, a set of 15 windows was selected so that the weightings were linearly distributed with a 5:1 ratio between the central window and the outermost windows. The following equation was used to filter the gamma-ray logs for all of the wells at the NWIRP site:

$$
\begin{aligned}
\text { gamma }_{i}= & 0.023 \times g_{i-7}+0.037 \times g_{i-6}+0.050 \times g_{i-5} \\
& +0.063 \times g_{i-4}+0.076 \times g_{i-3}+0.090 \times g_{i-2} \\
& +0.103 \times g_{i-1}+0.116 \times g_{i}+0.103 \times g_{i+1} \\
& +0.090 \times g_{i+2}+0.076 \times g_{i+3}+0.063 \times g_{i+4} \\
& +0.050 \times g_{i+5}+0.037 \times g_{i+6}+0.023 \times g_{i+7},
\end{aligned}
$$

where

$$
\begin{aligned}
\text { gamma }_{\mathrm{i}}= & \text { filtered gamma radiation, in counts per } \\
& \text { second, } \\
\mathrm{g}_{\mathrm{i}}= & \text { actual gamma radiation, in counts per } \\
& \text { second, and } \\
\mathrm{i}= & \text { central window. }
\end{aligned}
$$

The filter had a smoothing effect on the graphical output of the logs, which aided in the interpretation of the relative clay content of sediments (fig. 2).
The interpretation of lithology from gamma-ray logs begins with generalization of the gamma-ray log data using the digital filter and classification by comparing the filtered log data with existing lithologic log data. The filtering removed the statistical variations inherent in gamma radiation, whereas the classification aided in visual interpretation and separation of the log data into low, intermediate, and high clay-content sediments. Exploratory analysis of the filtered logs, in conjunction with their associated lithologic descriptions, provided values used in the development of an algorithm to separate the filtered gamma-ray log data into three groups on the basis of relative clay content. Classification of the gamma-ray data into low (less than $50 \mathrm{cps}$ ), intermediate (50 to $55 \mathrm{cps}$ ), and high (greater than $55 \mathrm{cps}$ ) relative clay content (fig. 2) simplified the process of correlating the well logs to develop lithologic sections.

\section{Cone-Penetrometer Test Log Processing and Analysis}

The CPT logs were incorporated into the geophysical analysis by modifying in-house software to scale digitized CPT line files to the same depth intervals $(0.1 \mathrm{ft})$ as the gamma-ray log data to linearly interpolate CPT values for intervals with missing values. CPTlogged wells adjacent to gamma-ray-logged wells were used subsequently in a trial-and-error approach to determine an appropriate coefficient (75) to scale CPT log data to gamma-ray log data (fig 3). The scaled CPT log data were then processed with the same software used to classify the gamma-ray log data.

\section{Electromagnetic-Induction Log Processing and Analysis}

The EM-induction logging tool uses an electromagnetic field to induce an electric current through the materials surrounding the borehole and measures conductivity, in millisiemens per meter, and inversely, the resistivity, in ohm-meters, of the materials within about $3 \mathrm{ft}$ of the detector. The conductivity data for wells with no detected contaminants in the water (EnSafe/Allen \& Hoshall, 1996b) were analyzed to determine the natural variability of conductivity for each of the sediment classes defined with the gamma-ray log data. Boxplots used in an initial exploratory analysis of the conductivity data indicated that for the majority of the data (interquartile range), conductivities generally increased as 


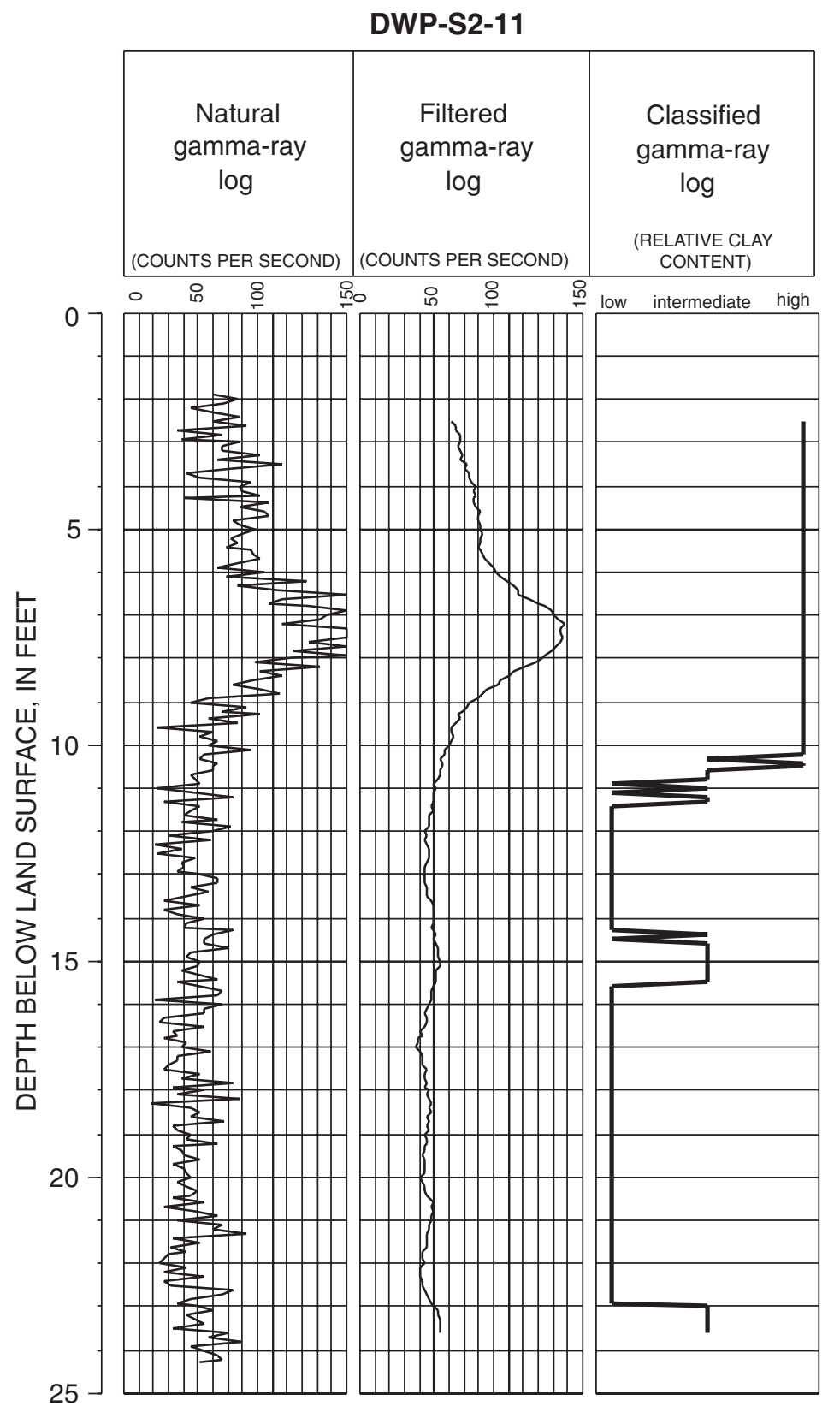

Figure 2. Comparison of natural, filtered, and classified gamma-ray log data.

relative clay content increased (fig. 4). The Wilcoxon rank-sum test (Helsel and Hirsch, 1992) was used to determine whether conductivities for high clay-content sediments are the same as conductivities for intermediate clay-content sediments, whether conductivities for intermediate clay-content sediments are the same as conductivities for low clay-content sediments, and whether conductivities for low clay-content sediments are the same as conductivities for high clay-content sediments. The tests indicated a statistically significant difference at the $\alpha=0.05$ significance level (two-sided p-value $<=0.0000$ ), thus providing an independent validation of the gamma-ray-based sediment classes.

The generally small concentrations of contaminants within the subsurface plume (EnSafe/Allen \& Hoshall, 1994, 1996a) and mostly high relative clay content of sediments within the study area (Braun and others, 2000, appendix) prohibited a directly quantifiable relation between conductivity and vertical distribution of the contaminant plume. A dataset of conduc- 


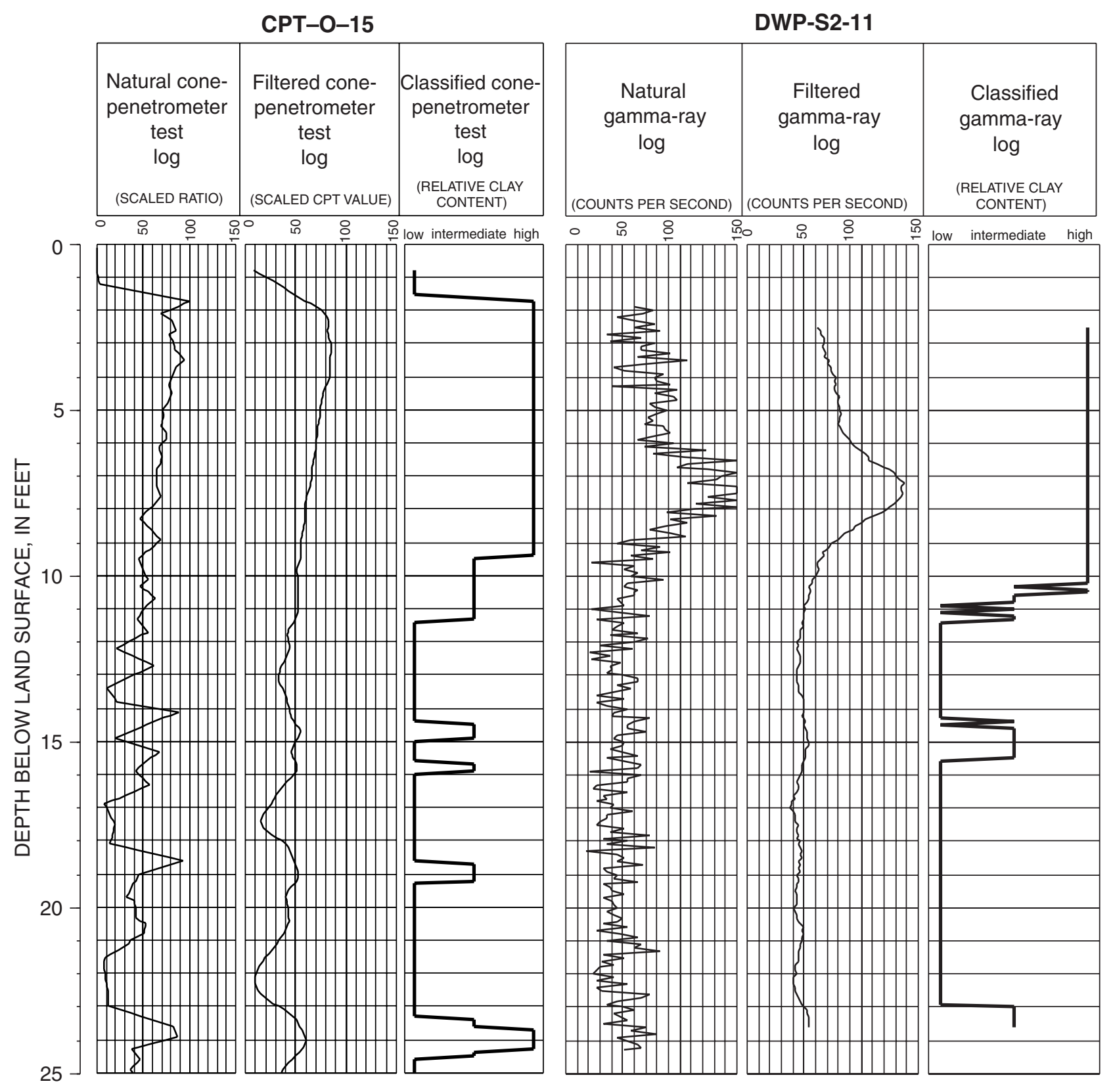

Figure 3. Comparison of a cone-penetrometer test (CPT) log and a nearby gamma-ray log.

tivities from the log data for wells with no detected contaminants in the water was used to establish a baseline for the natural distribution of conductivity within the aquifer materials. The statistical medians and standard deviations were determined for low, intermediate, and high clay-content sediments (table 1). Conductivities greater than or equal to the median plus one standard deviation for each of the sediment classes were interpreted as indicators of potentially contaminated sediments. Conductivities equal to or greater than 155.63
$\mathrm{mS} / \mathrm{m}$ for low clay-content sediments and equal to or greater than $194.68 \mathrm{mS} / \mathrm{m}$ for intermediate clay-content sediments indicate potential contamination. Anomalous conductivities (equal to or greater than these limits) were plotted on the lithologic sections to indicate zones of potential contamination. Conductivities for high clay-content sediments were not used to identify potentially contaminated zones because of the increased variance in conductivity associated with increases in relative clay content. The interquartile range in conduc- 


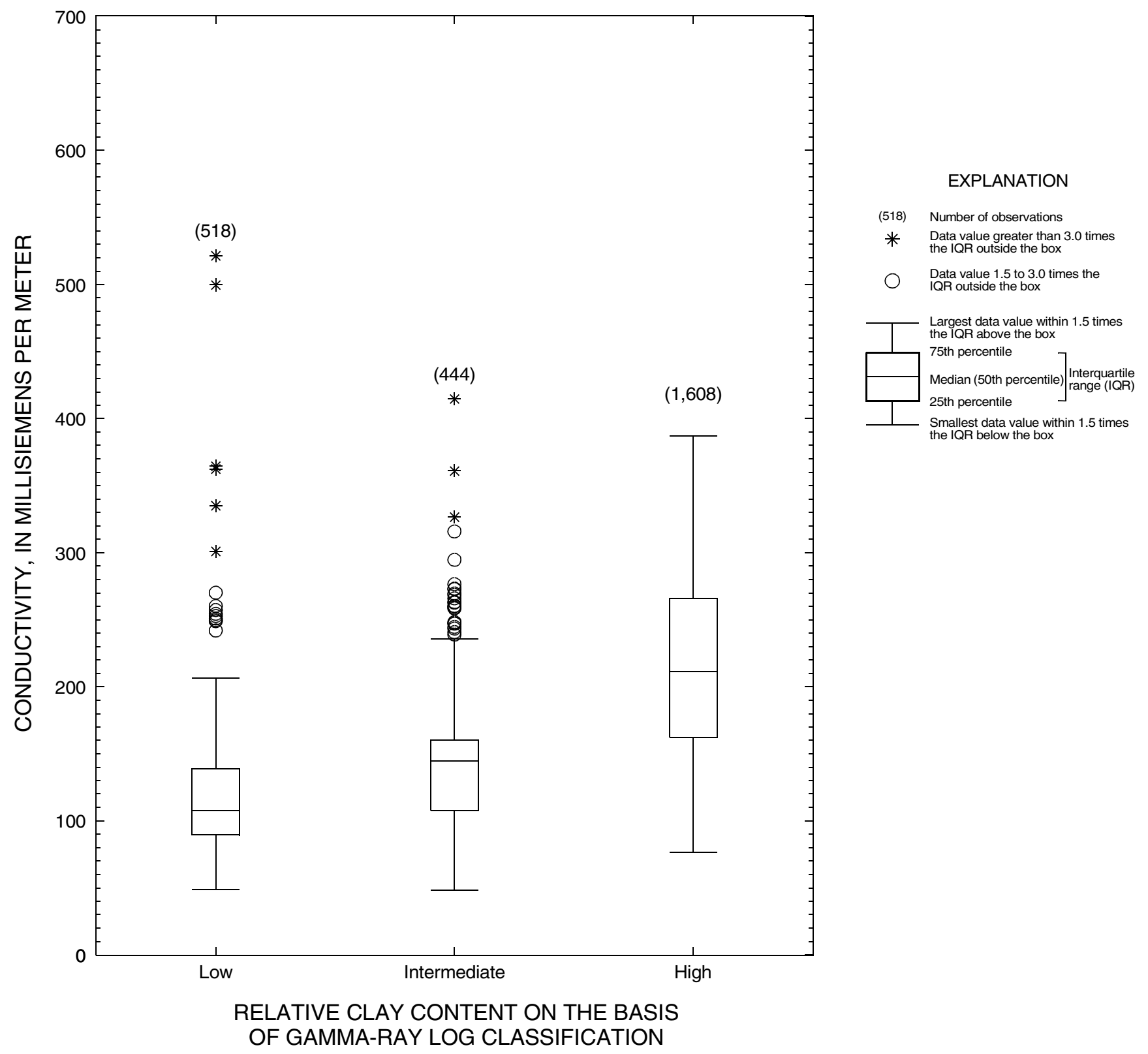

Figure 4. Range and distribution of conductivity for wells with no detected contaminants.

tivity for high clay-content sediments $(103 \mathrm{mS} / \mathrm{m})$ was about 2 times that for low $(49 \mathrm{mS} / \mathrm{m})$ and intermediate (52 $\mathrm{mS} / \mathrm{m}$ ) clay-content sediments (fig. 4).

\section{SITE CHARACTERIZATION}

The alluvium at NWIRP typically has low permeability; a low clay-content classification from the well logs indicates the most permeable zone of this low permeability alluvium. Lithologic sections aid in mapping continuous relatively permeable zones within the alluvium. The intersecting sections provide locations where
Table 1. Statistics for clay-content sediment classes in uncontaminated areas of the shallow alluvial aquifer $[\mathrm{mS} / \mathrm{m}$, millisiemens per meter]

\begin{tabular}{lccc}
\hline \multirow{2}{*}{ Sediment class } & \multicolumn{3}{c}{ Conductivity (mS/m) } \\
\cline { 2 - 4 } & Mean & Median & $\begin{array}{c}\text { Standard } \\
\text { deviation }\end{array}$ \\
\hline Low clay & 118.38 & 107.49 & 48.14 \\
Intermediate clay & 144.72 & 144.97 & 49.71 \\
High clay & 217.27 & 211.18 & 62.25 \\
\hline
\end{tabular}


the interpretation of the individual sections must agree, thus substantiating the interpretations. Many, but not all, of the logs collected are displayed on 10 interpreted sections; the locations of these sections are shown on plate 1. (The logs collected by the USGS were interpreted and graphically plotted by Braun and others (2000).)

Zones of thinly bedded low to high clay-content sediment classes (gamma-ray data between 50 and 55 cps) were interpreted as units of intermediate clay content on the sections. The gamma-ray logs did not always support the field-interpreted lithologic descriptions.

Bentonitic chips used in the construction of each of the wells resulted in gamma-ray data in excess of $120 \mathrm{cps}$, thereby masking the gamma-ray signal derived from the lithology. This resulted in counter-intuitive interpretations in which clay content and gamma-ray log classification did not agree. In most cases, however, the discrepancies were attributed to the difficulty of interpreting very fine sediments in the field, as opposed to the more detailed laboratory analysis for grain-size distribution and mineralogy.

Of the 10 sections, the first seven, $A-A^{\prime}, C-C^{\prime}$, $D-D^{\prime}, F-F^{\prime}, G-G^{\prime}, L-L^{\prime}$, and $M-M^{\prime}$ (pls. 2-3), were selected to closely correspond to existing sections generated by EnSafe/Allen \& Hoshall (1996a). Sections $P-P^{\prime}, Q-Q^{\prime}$, and $R-R^{\prime}$ (pl. 3) were added subsequently to provide additional detail for a multilayer groundwater model in areas underrepresented by the first seven sections.

The sections (pls. 2-3) indicate three major sedimentary units in the shallow alluvial aquifer at NWIRP. The lower unit, consisting of relatively permeable, low clay-content sediments overlain by a fairly continuous layer of relatively impermeable sediments, lies directly on top of the Eagle Ford Shale. The lower unit is overlain by a middle unit consisting of complex, discontinuous, relatively permeable and impermeable facies, probably representing thin meander belts of fine sands and vertical accretion of floodplain deposits of silt and clay. The middle unit is overlain by a mostly continuous upper unit, consisting of relatively permeable sediments, overlain by a mostly continuous zone of relatively impermeable clay sediments at land surface. Small scale, fining-up sequences, characteristic of fluvial systems, also were identified in all sections but were not determined to be laterally continuous across NWIRP.
In the lower unit, the permeable zone has a maximum thickness of about $20 \mathrm{ft}$ at CPT-T-9 on section $L-L^{\prime}$ (pl. 3). Although this unit is fairly continuous across most of the study area, it is absent in the southeastern part of the site along sections $D-D^{\prime}$ and $Q-Q^{\prime}$ as well as in the northwestern part along section $R-R^{\prime}$ (pls. 2-3).

The complex, discontinuous middle unit varies in thickness from about $15 \mathrm{ft}$ at CPT-EOD-8 on section $G-G^{\prime}$ to about $30 \mathrm{ft}$ at CPT-J-23 on section $A-A^{\prime}$ (pls. 2-3). Permeable zones were absent from this unit mostly in the southeastern, northern, and northwestern part of the site, along parts of sections $A-A^{\prime}, D-D^{\prime}$, $F-F^{\prime}$, and $R-R^{\prime}$. A single, continuous permeable zone is present in the western part of the site along the entire length of sections $L-L^{\prime}$ and $P-P^{\prime}$. Along sections $F-F^{\prime}$, $G-G^{\prime}, M-M^{\prime}$, and $R-R^{\prime}$ in the western part of the site, the permeable zones are highly discontinuous and commonly either present as two distinct zones or absent altogether.

The permeable zone in the upper unit has a maximum thickness of about $25 \mathrm{ft}$ at DWP-L2-DW1 on section $A-A^{\prime}$ (pl. 2). This unit has been eroded by recent fluvial processes and replaced by fill material mostly in the eastern and southeastern part of the site, along parts of sections $D-D^{\prime}, F-F^{\prime}, G-G^{\prime}, L-L^{\prime}$, and $Q-Q^{\prime}$ (pls. 2-3). However, the unit is laterally continuous and fairly uniform in thickness along parts of sections $G-G^{\prime}$, $P-P^{\prime}$, and $Q-Q^{\prime}$.

The relatively impermeable clay zone at land surface ranges in thickness from 0 at DWP-BG-6 on section $A-A^{\prime}$ to about $30 \mathrm{ft}$ at CPT-R-34 on section $R-R^{\prime}$ (pls. 2-3). Relatively permeable fill material has replaced some or all of this zone in the southeastern part of the site, including parts of sections $D-D^{\prime}, F-F^{\prime}, L-L^{\prime}$, and $M-M^{\prime}$.

The EM-conductivity log analysis indicated the location of potentially contaminated zones generally within the uppermost clay layer except in the small filled valley area in the southeastern part of the site, where the potentially contaminated zones were within and beneath the fill material (sections $D-D^{\prime}, F-F^{\prime}$, and $\left.M-M^{\prime}\right)$. The potentially contaminated zones generally appear to be local occurrences. 


\section{SUMMARY}

A shallow alluvial aquifer at the Naval Weapons Industrial Reserve Plant near Dallas, Texas, has been contaminated by organic solvents used in the fabrication and assembly of aircraft and aircraft parts. Previous studies indicate that the aquifer ranges in thickness from about 10 to about $75 \mathrm{ft}$ and consists of three distinct water-yielding zones overlying a confining bedrock unit. During July and August 1997, the USGS collected borehole geophysical data from 162 polyvinyl-chloridecased wells on NWIRP. The natural gamma-ray and EM-induction log data were integrated with existing lithologic and CPT log data to improve site characterization of the subsurface alluvium.

Software was developed for filtering and classifying the log data and for processing, analyzing, and creating graphical output of the digital data. The alluvium consists of mostly fine-grained low-permeability sediments. For this study, the alluvium was classified into low, intermediate, and high clay-content sediments on the basis of the gamma-ray logs. The low clay-content sediments were interpreted as being relatively permeable, whereas the high clay-content sediments were interpreted as being relatively impermeable. Simple statistics were used to identify zones of potentially contaminated sediments on the basis of the gamma-ray log classifications and the EM-conductivity log data. The statistics derived from the conductivity data validated the gamma-ray clay-content classifications. Gammaray, CPT, and EM logs were used to develop a series of intersecting sections to delineate the spatial distribution of low, intermediate, and high clay-content sediments and the zones of potentially contaminated sediments.

The sections indicate three major sedimentary units in the shallow alluvial aquifer at NWIRP. The lower unit consists of relatively permeable, low claycontent sediments and is absent over the southeastern and northwestern part of the site. Permeable zones in the complex, discontinuous middle unit are present mostly in the western part of the site. In the eastern and southeastern part of the site, the upper unit has been eroded away and replaced by fill material. Zones of potentially contaminated sediments are generally within the uppermost clay layer or fill material. In addition, the zones tend to be local occurrences.

\section{REFERENCES}

Braun, C.L., Anaya, Roberto, and Kuniansky, E.L., 2000, Borehole geophysical logs at Naval Weapons Industrial Reserve Plant, Dallas, Texas: U.S. Geological Survey Open-File Report 00-076, 232 p.

Dallas Geological Society, 1965, The Geology of Dallas County-Symposium on Surface and Subsurface Geology, Gravity, Physiography, Underground Water Supply, Economic Geology, and Engineering Geology of Dallas County: Dallas, Tex., Dallas Geological Society, 211 p.

EnSafe/Allen \& Hoshall, 1994, Comprehensive long-term environmental action-Navy stabilization work planRevision I: Memphis, Tenn., EnSafe/Allen \& Hoshall, $83 \mathrm{p}$.

1996a, Draft RCRA Facility Investigation report, Naval Weapons Industrial Reserve Plant, Dallas, Texas-Volume I (Sections 1-5): Memphis, Tenn., EnSafe/Allen \& Hoshall [variously paged].

1996b, Draft RCRA Facility Investigation report, Naval Weapons Industrial Reserve Plant, Dallas, Texas-Volume III (Sections 7-10): Memphis, Tenn., EnSafe/Allen \& Hoshall [variously paged].

1996c, Draft RCRA Facility Investigation report, Naval Weapons Industrial Reserve Plant, Dallas, Texas-Volume VI (Appendices E-J): Memphis, Tenn., EnSafe/Allen \& Hoshall [variously paged].

Helsel, D.R., and Hirsch, R.M., 1992, Studies in environmental science 49-Statistical methods in water resources: New York, Elsevier, 522 p.

Jones, S.A., and Paillet, F.L., 1997, Integrity of production wells and confining unit at the Naval Weapons Industrial Reserve Plant, Dallas, Texas, 1995: U.S. Geological Survey Water-Resources Investigations Report 97-4047, $30 \mathrm{p}$.

Keys, W.S., and MacCary, L.M., 1971, Application of borehole geophysics to water-resources investigations: U.S. Geological Survey Techniques of Water-Resources Investigations Report, book 2, chap. E1, 126 p.

McNeill, J.D., Bosnar, M., and Snelgrove, F.B., 1990, Resolution of an electromagnetic borehole conductivity logger for geotechnical and ground water applications: Mississaugua, Ontario, Canada, Geonics Limited, Technical Note $\mathrm{TN}-25,28 \mathrm{p}$.

Ramos, M.G., ed., 1997, Texas almanac, 1998-1999: The Dallas Morning News, 672 p.

Schlumberger, 1972, Log interpretation, volume I-Principles: New York, Schlumberger Limited, 112 p.

Williams, J.H., Lapham, W.W., and Barringer, T.H., 1993, Application of electromagnetic logging to contamination investigations in glacial sand-and-gravel aquifers: Ground Water Monitoring, p. 129-138. 